\title{
PENERAPAN USER CENTERED DESIGN (UCD) UNTUK SISTEM INFORMASI PERIJINAN PADA PT. ALFA GOLDLAND REALTY TANGERANG SELATAN
}

\author{
Ivo Grizelda ${ }^{1}$, Wisti Dwi Septiani ${ }^{2 *}$ \\ ${ }^{1}$ Sistem Informasi \\ Universitas Bina Sarana Informatika \\ www.bsi.ac.id \\ grizeldaivo@gmail.com ${ }^{1}$; wisti.wst@bsi.ac.id ${ }^{2 *}$ \\ *corresponding author
}

\begin{abstract}
The basic necessities of human life besides clothing and food are boards or what is commonly known as a house. House made human as a shelter for the survival of life. Therefore, no doubt everyone wants a comfortable and safe house. If there is damage to the house, renovations or repairs must be done so that its function is still good and can continue to support a good life. PT. Alfa Goldland Realty is an estate management office that does business in the area of integrated residential area providers. One of the activities carried out is to serve the application for building renovation permits. In its implementation before the house renovation is carried out, consumers must submit a renovation permit to the office of the manager. Licensing is one of the important aspects in public services and the regulation and control of the process that will be carried out. Constraints experienced by PT. Alfa Goldland Realty in the licensing service for submitting renovations is a lengthy, time-consuming procedure for one customer, giving rise to an image of inadequate service. Currently the staff handling the licensing process is still limited and inadequate with the many requests for renovation from consumers. Using the paper as a media in the renovation permit process makes the process less effective and efficient. The low quality of service that currently drives PT. Alfa Goldland Realty must immediately improve the quality of its services. The solution needed to PT. Alfa Goldland Realty is the implementation of information systems with the User Centered Design (UCD) method. This method is used for the design of information systems that are seen from the user or user side, so that user needs will be the basis of how the system is designed. The results of this study are web-based information systems that can be accessed by consumers and management offices for the licensing process so that the activities run more effectively and efficiently.
\end{abstract}

Keywords: public service, permit, user centered design, information system.
Intisari-Kebutuhan pokok hidup manusia selain sandang dan pangan adalah papan atau yang akrab dikenal dengan sebutan tempat tinggal atau rumah. Hunian atau rumah dijadikan manusia sebagai tempat berteduh untuk keberlangsungan kehidupan. Oleh karena itu tidak dipungkiri semua orang menginginkan hunian yang nyaman dan aman. Jika terjadi kerusakan pada rumah maka harus dilakukan renovasi atau perbaikan agar fungsinya tetap baik dan dapat terus menunjang kehidupan yang baik. PT. Alfa Goldland Realty adalah kantor pengelola (estate management) yang melakukan bisnis di bidang penyedia kawasan hunian terpadu. Salah satu aktivitas yang dilakukan adalah melayani pengajuan perijinan renovasi bangunan. Dalam pelaksanaannya sebelum dilakukan renovasi rumah, konsumen harus melakukan pengajuan izin renovasi kepada kantor pengelola tersebut. Perijinan merupakan salah satu aspek penting dalam pelayanan publik dan pengaturan serta pengendalian terhadap proses yang akan dilakukan. Kendala yang dialami PT. Alfa Goldland Realty dalam pelayanan perijinan pengajuan renovasi adalah prosedur yang panjang, memakan waktu banyak untuk satu konsumen, sehingga menimbulkan citra sebagai pelayanan yang kurang baik. Saat ini staf yang menangani proses perijinan tersebut masih terbilang terbatas dan tidak mencukupi dengan banyaknya permintaan renovasi dari konsumen. Penggunaan media kertas dalam proses perijinan renovasi menjadikan prosesnya kurang efektif dan efisien. Rendahnya kualitas pelayanan saat ini yang mendorong PT. Alfa Goldland Realty harus segera memperbaiki kualitas pelayanannya. Solusi yang dibutuhkan PT. Alfa Goldland Realty adalah dengan implementasi sistem informasi dengan metode User Centered Design (UCD). Metode ini digunakan untuk perancangan sistem informasi yang dilihat dari sisi penguna atau user, sehingga kebutuhan user yang akan menjadi dasar bagaimana sistem ini dirancang. Hasil dari penelitian ini adalah sistem informasi berbasis web yang dapat diakses oleh 
konsumen dan kantor pengelola untuk proses perijinan sehingga kegiatan tersebuh berjalan lebih efektif dan efisien.

Kata Kunci: pelayanan publik, perijinan, user centered design, sistem informasi.

\section{PENDAHULUAN}

PT. Alfa Goldland Realty merupakan perusahaan yang berkembang di bidang bisnis property dengan menyediakan kawasan hunian terpadu yang mengedepankan kualitas dan inovasi. Saat ini PT. Alfa Goldland Realty berusaha meningkatkan kompetensi sumber daya manusia dan kinerja perusahaan dengan memanfaatkan perkembangan teknologi informasi lebih optimal agar dapat melayani konsumen dengan baik. Salah satu aktivitas yang dilakukan oleh PT. Alfa Goldland Realty sebagai kantor pengelola (estate management) adalah melayani perijinan renovasi bangunan dari konsumen. Seiring dengan permintaan masyarakat akan hunian yang nyaman menimbulkan tingginya frekuensi pengajuan perijinan renovasi. Kendala yang dihadapi dalam proses perijinan selama ini adalah prosedur yang panjang dan memakan waktu banyak menimbulkan antrian yang mengakibatkan ketidaknyamanan pelanggan dalam menggunakan jasa tersebut (Ramanda \& Yunita, 2019). Proses pencatatan dan perekapan data masih menggunakan buku agenda manual, sehingga data yang ada dalam agenda tersebut bisa hilang, terbakar atau terkena banjir (Akbar, Nainggolan, \& Khasanah, 2019). Saat ini PT. Alfa Goldland Realty belum maksimal dalam memanfaatkan kemajuan TIK yang mencakup dua aspek yaitu teknologi infomasi dan teknologi komunikasi (Ibrahim \& Septiani, 2017).

Solusi yang dibutuhkan untuk menangani permasalah tersebut adalah dengan perancangan sistem informasi berbasis web dengan menerapkan metode User Centered Design (UCD) dengan tujuan dapat mengatasi masalah ketidakmampuan pengguna dalam menggunakan system dan diharapkan pengguna mampu mengetahui fungsi sistem hanya dalam sekali pakai. (Saputri, Sandra, Fadhli, \& Surya, 2017). Website yang dibuat akan fokus pada pengguna yaitu konsumen (pemohon) dan bagian pelayanan dimana kondumen dapat mengajukan permohonan perijinan melalui website yang dapat diakses dari rumah, mengisi persyaratan, mengirimkan gambaran renovasi yang diinginkan. Selain itu konsumen juga dapat mengontrol perkembangan status pendaftaran sehingga prosesnya dapat berjalan lebih efektif dan efisien baik dari sisi konsumen ataupun dari sisi kantor pengelola.

\section{BAHAN DAN METODE}

Metode pengumpulan data yang dilakukan penulis adalah Observasi (Observation) dan Wawancara (Interview). Observasi dengan melakukan pengamatan langsung pada objek yang diteliti dengan mempelajari sistem yang berjalan saat ini yaitu proses perijinan serta dokumendokumen yang terlibat dalam system. Wawancara dengan melakukan tanya jawab dengan pihak Kantor Pengelola Estate Management untuk mengetahui sistem yang berjalan dan kendala apa saja yang ditemui dalam proses perijinan tersebut. Hasil dari observasi dan wawancara inilah yang dijadikan penulis sebagai bahan atau dasar untuk perancangan sistem informasi pada PT. Alfa Goldland Realty.

Metode yang digunakan dalam perancangan sistem informasi perijinan berbasis web ini adalah User Centered Design (UCD). UCD adalah sebuah metode pembangunan sistem yang memiliki konsep bahwa user sebagai pusat dari proses pengembangan sistem (Kurniawati, Safitri, \& Akbar, 2019), dan tujuan/sifat-sifat, konteks dan lingkungan sistem semua didasarkan dari pengalaman pengguna. User Centered Design adalah pengembangan sistem yang dirancang dengan berfokus pada pengguna dengan fleksibel dan interaktif (Anugrah, Santoso, \& Budi, 2019). Terdapat 5 tahapan dalam aktivitas UCD yang saling ketergantungan (Albani \& Lombardi, 2010), tahapan tersebut dapat dilihat pada gambar 1.

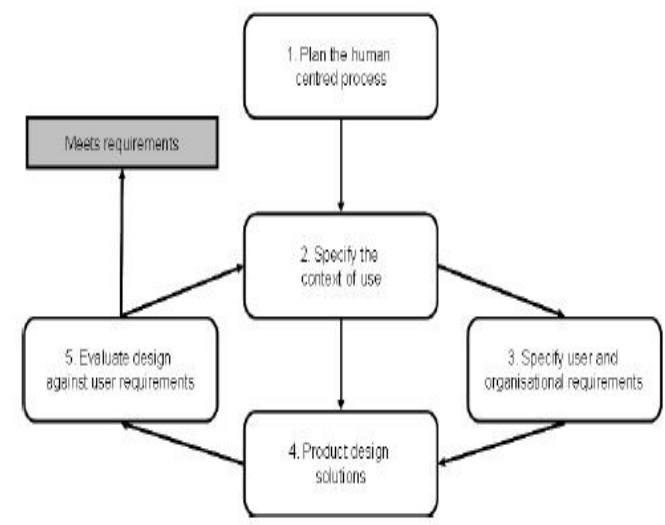

Sumber: (Albani \& Lombardi, 2010) Gambar 1. Tahapan UCD

\section{HASIL DAN PEMBAHASAN}

Pada perancangan sistem informasi perijinan, penulis melakukan analisa UCD yang memiliki 5 tahapan sebagai berikut: (1) Plan the human centred process atau Tahap Perencanaan pada UCD, (2) Specify the context of use atau 
menentukan konteks pengguna, (3) Specify the user and organizational requirements atau menentukan kebutuhan pengguna dan organisasi, (4) Produce design solutions atau solusi desain yang dihasilkan, dan (5) Evaluate design against user requirements atau evaluasi desain terhadap kebutuhan pengguna.

\section{A. Plan the human centred process atau tahap Perencanaan pada UCD}

Pada pihak ini penulis melakukan perencanaan dengan berdiskusi terkait perancangan sistem informasi perijinan yang berpusat pada pengguna. Diskusi dilakukan dengan pihak kantor pengelola untuk mengetahui kebutuhan sistem yang akan dibangun.

\section{B. Specify the context of use atau menentukan konteks pengguna}

Sistem informasi perijinan yang akan dirancang merupakan aplikasi berbasis web, dimana website dapat diakses oleh konsumen (pemohon) dan bagian pelayanan di kantor pengelola. Pada tahapan ini penulis melakukan identifikasi pengguna sistem dengan melakukan diskusi dengan pihak kantor pengelola selaku bagian pelayanan untuk memberi gambaran rancangan sistem informasi yang akan dibangun dan menjelaskan fungsi-fungsinya. Target yang ingin dicapai oleh kantor pengelola terhadap kebutuhan konsumen adalah: Konsumen Satu, konsumen Dua, konsumen Tiga.

\section{Specify the user and organizational requirements atau menentukan kebutuhan pengguna dan organisasi}

Pada tahap ini penulis melakukan identifikasi terhadap kebutuhan sistem informasi perijinan pada PT. Alfa Glodland Realty untuk keperluan proses pendaftaran perijinan yang akan dirancang yaitu (1) kebutuhan data informasi, yaitu data pemohon dan data bagian pelayanan. (2) kebutuhan fungsional sistem yang dibangun merupakan aplikasi web, sistem dapat mengelola data master yaitu data pemohon dan data bagian pelayanan, lalu data transaksi yaitu pendaftaran perijinan, dan pencetakan laporan yang diperlukan.

Analisa kebutuhan pengguna terdiri dari:

a. Analisa Kebutuhan Pemohon

- Pemohon dapat melakukan login

- Pemohon dapat mengajukan pendaftaran perizinan dan mengunggah gambar rencana renovasi

- Pemohon dapat mengecek status pengajuan
- Pemohon mendapat formulir pelaksanaan pekerjaan yang telah disetujui oleh bagian pelayanan

b. Analisa Kebutuhan Bagian Pelayanan

- Petugas dapat melakukan login

- Petugas dapat mengelola data pengajuan perizinan

- Petugas dapat mengelola data pemohon

- Petugas dapat melakukan validasi formulir \& berkas persyaratan

- Petugas dapat mengelola data pembayaran

- Petugas dapat melihat dan mencetak laporan pengjuan perizinan

- Petugas dapat logout

\section{Produce design solutions atau solusi desain yang dihasilkan}

Pada tahap ini penulis melakukan perancangan untuk menghasilkan website yang merupakan solusi dari permasalahan yang ditemui, perancangan terdiri dari tahapan-tahapan yaitu: (a) use case diagram, (b) activity diagram, (c) entity relationship diagram (ERD), (d) desain antar muka implementasi website.

Use Case adalah deskripsi fungsi dari sebuah sistem dari perspektif pengguna. Use case bekerja dengan cara mendeskripsikan tipikal interaksi antar user (pengguna) sebuah sistem dengan sistemnya sendiri melalui sebuah cerita bagaimana sebuah sistem dipakai (Buani, 2017). Use Case Diagram Pemohon yang dapat dibentuk dari pencangan sistem informasi perizinan pada PT. Alfa Goldland Realty ini sebagai berikut:

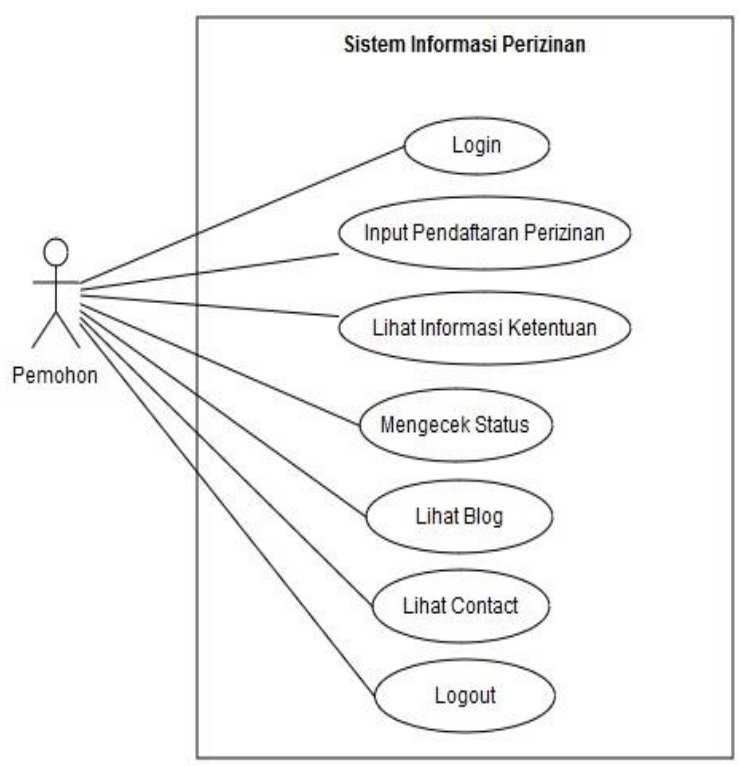

Sumber: (Septiani, 2019)

Gambar 2. Use Case Diagram Sistem Informasi Perijinan 
Activity diagram adalah teknik untuk mendeskripsikan logika procedural, proses bisnis dan aliran kerja dalam banyak Use Case. Activity diagram bisa digunakan untuk menunjukan siapa mengerjakan apa dengan teknik partision (Buani, 2017).

Berikut adalah activity diagram yang terbentuk dari use case diagram yang telah dibuat terlihat pada gambar 3.

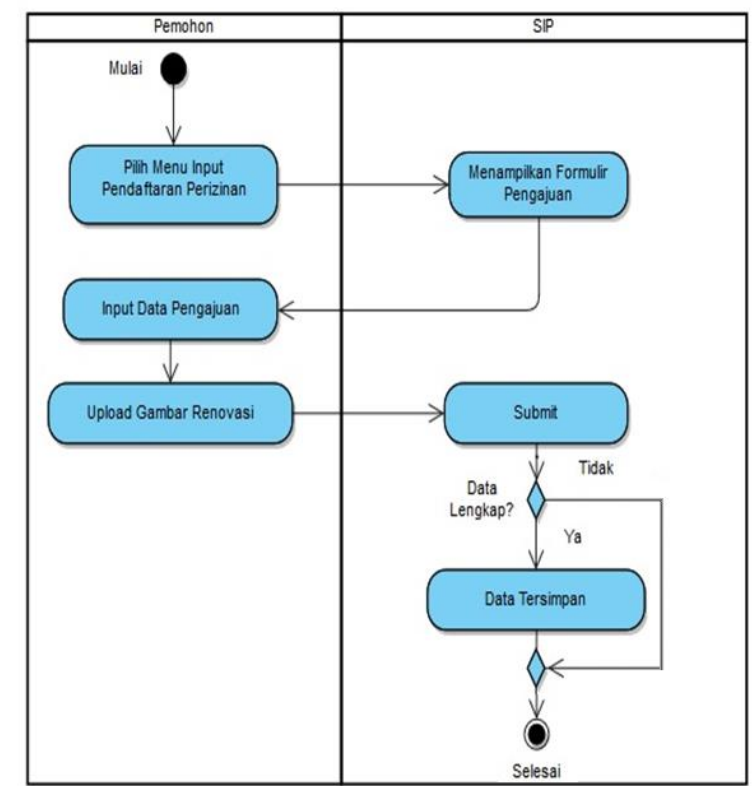

Sumber: (Septiani, 2019)

Gambar 3. Activity Diagram Input Pendaftaran Perijinan

Gambar 3 merupakan Activity Diagram Pendaftaran Perijinan dimana Pemohon memilih menu pendaftaran perijinan lalu tampil formulir pengajuan dan pemohon mengisi data secara lengkap serta mengunggah berkas persyaratan. Setelah itu pemohon klik submit dan sistem akan menyimpan data pengajuan pendaftaran lalu bagian pelayanan akan memeriksa memeriksa formulir pendaftaran dan berkas unggahan apakah sudah sesuai prosedur dan ketentuan yang berlaku. Jika data valid maka sistem akan mengirimkan RAB (Rancangan Anggaran Biaya) ke pemohon melalui email. Pemohon melakukan pelunasan, sistem menerima pembayaran dan kantor pengelola memproses form perjanjian waktu dan pelaksanaan kerja.

Perancangan Basis Data pada Sistem Informasi Perizinan digambarkan seperti ERD dibawah ini:

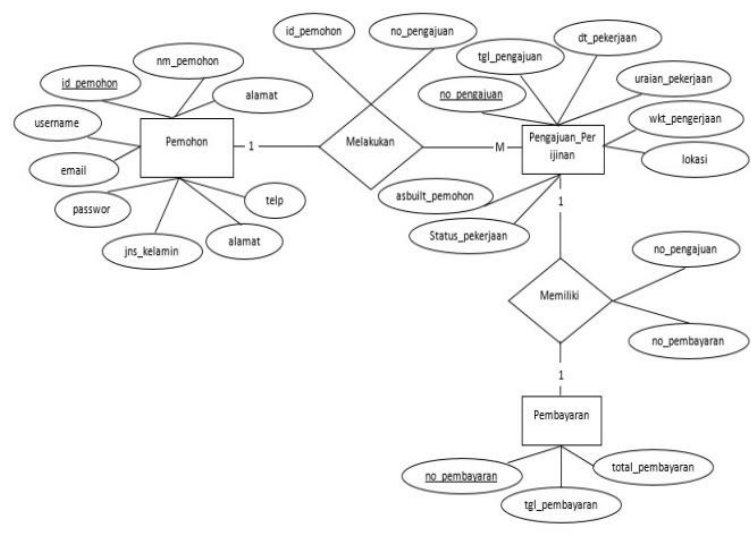

Sumber: (Septiani, 2019)

Gambar 4. ERD Sistem Informasi Perijinan

Setelah basis data terbuat maka dilakukan perancangan interface untuk implementasi sistem informasi perizinan berbasis web. Adapun interface sebagai berikut:

- Interface Menu Login Pemohon

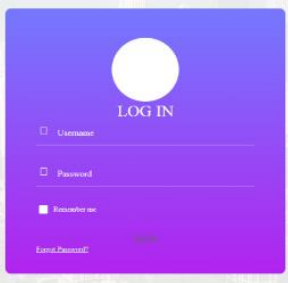

Sumber: (Septiani, 2019)

Gambar 5. Menu Login Pemohon

Gambar 5 merupakan halaman login pemohon. Pemohon menginput username dan password kemudian klik tombol login lalu masuk ke menu utama.

\section{- Interface Menu Utama Pemohon}

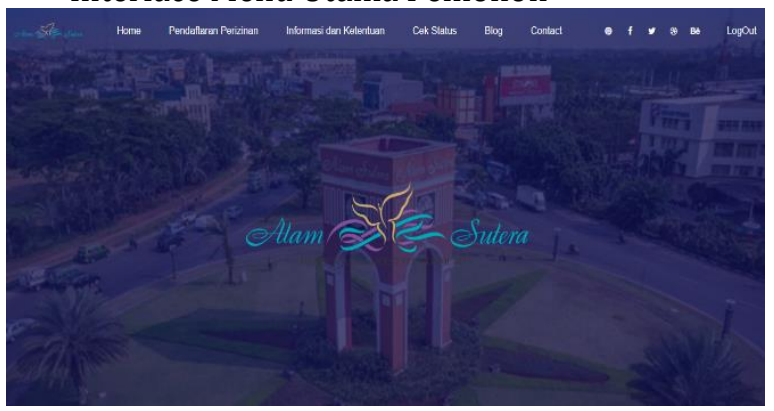

Sumber: (Septiani, 2019)

Gambar 6. Menu Utama Pemohon

Gambar 6 merupakan halaman menu utama pemohon terdiri dari menu Home, Pendaftaran Perijinan, Informasi dan Ketentuan, Cek Status, Blog dan Contact, serta akun sosial media. 
- Interface Menu Permohonan Perijinan

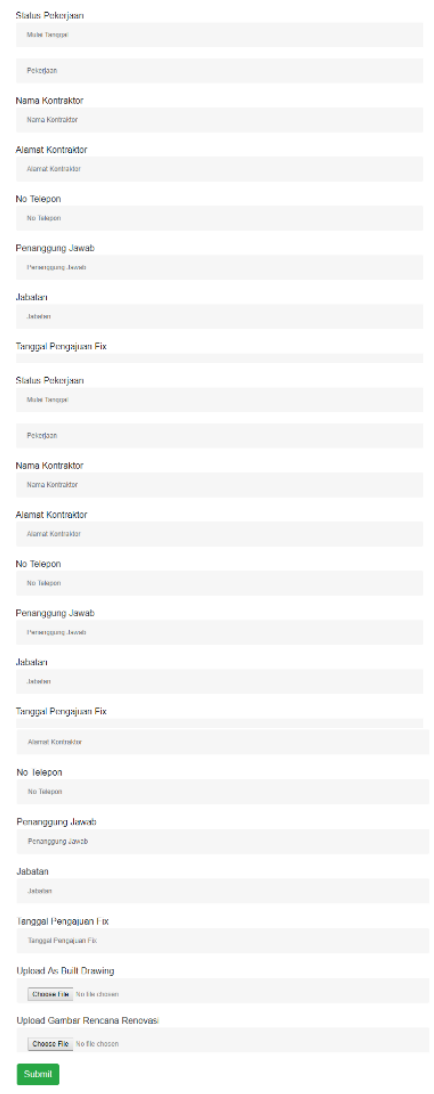

Sumber: (Septiani, 2019)

Gambar 7. Formulir Pendaftaran Perizinan

Gambar 7 merupakan formulir pendaftaran perijinan yang tampil saat pemohon memilih menu pendaftaran perijinan. Maka pemohon diwajibkan mengisi secara lengkap data-data yang dibutuhkan dan mengunggah gambar rancangan renovasi bangunan.

- Interface Menu Login Bagian Pelayanan

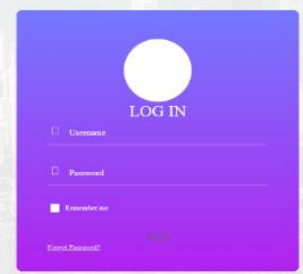

Sumber: (Septiani, 2019)

Gambar 8. Menu Login Bagian Pelayanan

Gambar 8 merupakan halaman login bagian pelayanan. Pemohon menginput username dan password kemudian klik tombol login lalu masuk ke menu utama.

- Interface Menu Dashboard Bagian Pelayanan

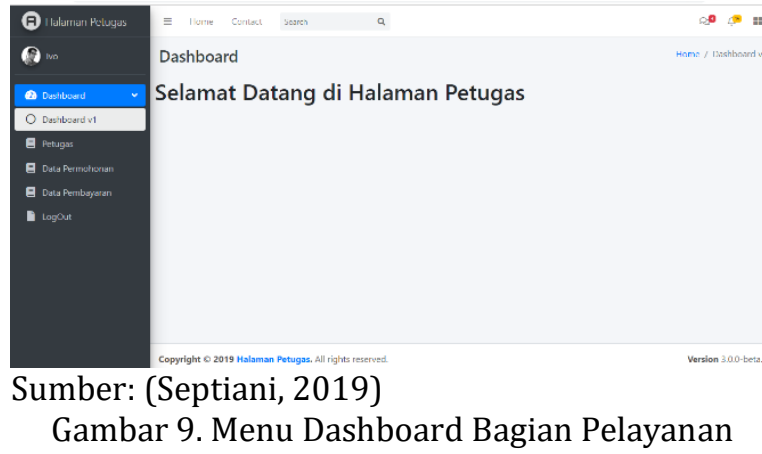

Gambar 9 merupakan menu dashboard administrator, bagian pelayanan dapat mengelola data pemohon, data pendaftaran perijinan, data pembayaram, data status dan mencetak laporan.

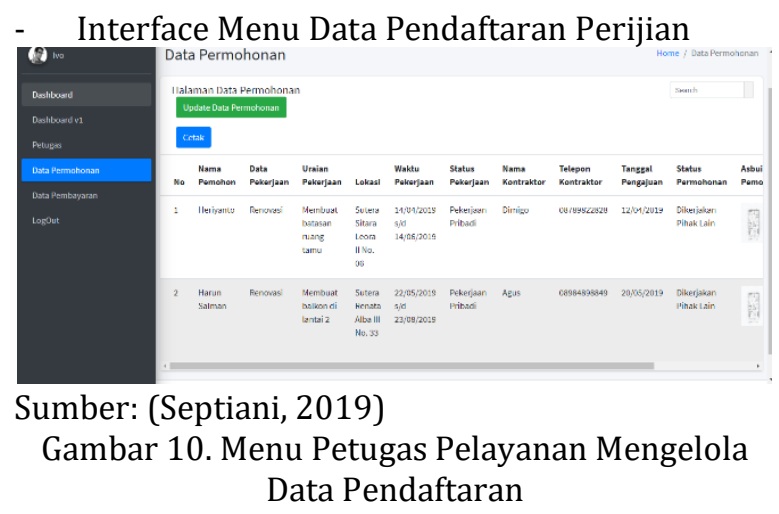

Gambar 10 merupakan menu bagian pelayanan mengelola data pendaftaran perijinan yang diajukan oleh pemohon.

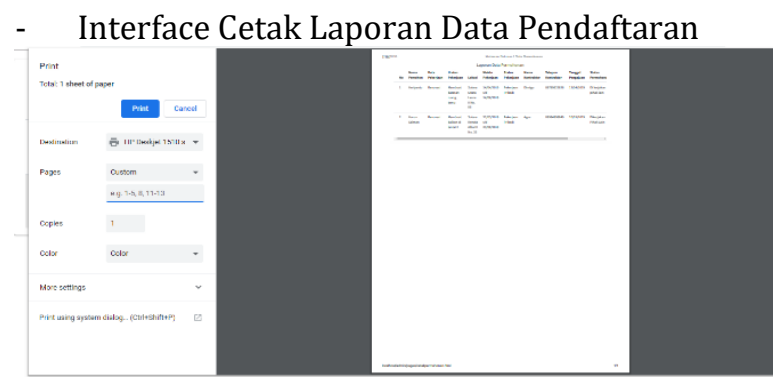

Sumber: (Septiani, 2019)

Gambar 11. Menu Bagian Pelayanan Cetak Laporan Data Pendaftaran

Gambar 11 merupakan menu bagian pelayanan mencetak laporan data pendaftaran perijinan.

\section{E. Evaluate design againt user requirements atau evaluasi desain terhadap kebutuhan pengguna}

Pada tahap ini penulis melakukan pengujian dengan metode blackbox, hasil pengujian blackbox terlihat pada tabel 1 . 
Tabel 1. Pengujian Blackbox

\begin{tabular}{|c|c|c|c|}
\hline Pengujian & Skenario Uji & $\begin{array}{c}\text { Hasil Yang } \\
\text { Diharapkan }\end{array}$ & Kesimpulan \\
\hline $\begin{array}{l}\text { Login } \\
\text { Benar }\end{array}$ & $\begin{array}{l}\text { Input } \\
\text { usernamse } \\
\text { dan } \\
\text { password } \\
\text { benar }\end{array}$ & $\begin{array}{l}\text { Berhasil login } \\
\text { dan masuk } \\
\text { kedalam } \\
\text { sistem }\end{array}$ & Sesuai \\
\hline $\begin{array}{l}\text { Login } \\
\text { Salah }\end{array}$ & $\begin{array}{l}\text { Input } \\
\text { username } \\
\text { dan } \\
\text { password } \\
\text { salah }\end{array}$ & $\begin{array}{l}\text { Login gagal } \\
\text { dan tidak } \\
\text { masuk } \\
\text { kedalam } \\
\text { sistem }\end{array}$ & Sesuai \\
\hline $\begin{array}{l}\text { Pendaftaran } \\
\text { Perijinan }\end{array}$ & $\begin{array}{l}\text { Pilih menu } \\
\text { Pendaftaran } \\
\text { Permohonan } \\
\text { lalu mengisi } \\
\text { permohonan } \\
\text { dengan } \\
\text { lengkap, lalu } \\
\text { klik tombol } \\
\text { simpan }\end{array}$ & $\begin{array}{l}\text { Menampilkan } \\
\text { form } \\
\text { permohonan } \\
\text { perijinan } \\
\text { kemudian } \\
\text { dapat mengisi } \\
\text { data dan } \\
\text { terdapat } \\
\text { tombol } \\
\text { simpan } \\
\end{array}$ & Sesuai \\
\hline $\begin{array}{l}\text { Cek Status } \\
\text { Perijinan }\end{array}$ & $\begin{array}{l}\text { Pilih menu } \\
\text { Cek Status } \\
\text { lalu akan } \\
\text { tampil status } \\
\text { dari proses } \\
\text { perijinan }\end{array}$ & $\begin{array}{l}\text { Menampilkan } \\
\text { status } \\
\text { perijinan yang } \\
\text { diajukan oleh } \\
\text { pemohon }\end{array}$ & Sesuai \\
\hline
\end{tabular}

Sumber: (Septiani, 2019)

\section{KESIMPULAN}

Berdasarkan penelitian yang telah dilakukan PT. Alfa Goldland Realty tentang sistem perijinan renovasi bangunan, dengan adanya perancangan sistem informasi perijinan berbasis web dengan metode UCD ini mendapatkan hasil sebagai berikut: Berdasarkan pendekatan dengan metode UCD didapatkan solusi berupa fasilitas pengajuan pendaftaran perizinan secara online melalui website sehingga mengurai kepadatan dan antrian saat proses pengajuan secara. Perancangan web dengan berpusat pada pengguna menghasilkan fasilitas upload gambar dari pengajuan renovasi sehingga memudahkan pemohon untuk menyiapkan desain terlebih dahulu dan memudahkan pelayanan dengan adanya waktu untuk mempelajari ajuan renovasi. Bagian pelayanan dapat lebih mudah membuat laporan berdasarkan data pengajuan pendaftaran perizinan yang tersimpan di database sehingga proses pembuatan laporan lebih efisien. Terjadinya transparansi antara bagian pelayanan dan pemohon yang dapat dipantau melalui website sehingga menghindari adanya aspek kecurangan dalam pelaksanaan di lapangan.

\section{REFERENSI}

Akbar, R., Nainggolan, E. R., \& Khasanah, S. N. (2019). Sistem Informasi Pelayanan Warga RW 01 Kelurahan Rawa Buaya Berbasis
Website. Jurnal Teknologi Sistem Informasi Dan Aplikasi, 2(3), 99. https://doi.org/10.32493/jtsi.v2i3.3254

Albani, L., \& Lombardi, G. (2010). User Centred Design for EASYREACH. (November 2010), 145.

Anugrah, C. S., Santoso, H. B., \& Budi, I. (2019). Rancang Bangun Aplikasi Wisata Halal Berbasis Android Menggunakan Metode User Centered Design. 314-321.

Buani, D. (2017). PERANCANGAN SISTEM INFORMASI KOPERASI SIMPAN PINJAM STUDI KASUS: KOPERASI SMK 18 LPPM RI SIDAREJA CILACAP. JITK, 3(1), 133-138.

Ibrahim, M. I., \& Septiani, W. D. (2017). Sistem Informasi Penerimaan Donasi ( Studi Kasus: Yayasan Sahabat Yatim Indonesia ). 3(1), 8794.

Kurniawati, L., Safitri, A., \& Akbar, D. D. (2019). User Centere Design (UCD) Untuk Rancang Bangun Sistem Informasi Pengolahan Data Simpan Pinjam Pada Koperasi. Jurnal Ilmu Pengetahuan Dan Teknologi Komputer, 4(1), 1-8. Retrieved from http://ejournal.nusamandiri.ac.id/ejurnal/in dex.php/jitk/article/view/839/491

Ramanda, K., \& Yunita, Y. (2019). Penerapan Metode Waiting Line Pada Pelayanan Antrian Pelanggan Jasa Ekspedisi. Jurnal Sisfokom (Sistem Informasi Dan Komputer), 8(1), 7. https://doi.org/10.32736/sisfokom.v8i1.586

Saputri, Y., Sandra, I., Fadhli, M., \& Surya, I. (2017). Penerapan Metode UCD (User Centered Design) Pada E-Commerce Putri Intan Shop Berbasis Web. Jurnal Nasional Teknologi Dan Sistem Informasi, 3(2), 269-278. https://doi.org/10.25077/teknosi.v3i2.2017. 269-278

Septiani, W. D. (2019). Laporan Akhir Penelitian. Jakarta. 